Original Article

\title{
Study on Number of Purkinje Cell of Cerebellum in Bangladeshi Cadaver
}

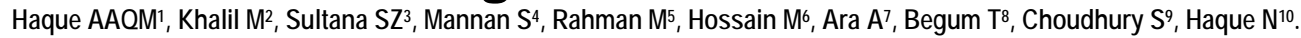

\begin{abstract}
This cross sectional descriptive study was performed by examining 30 (thirty) relatively fresh cerebellum of Bangladeshi cadaver of both sexes and samples were collected by using nonprobability sampling technique. Out of them 20 postmortem human cerebellum collected from Bangladeshi cadavers of both sexes (male 10 and female 10) age ranging from 5 to 60 years and 10 cerebellums from caesarian section of dead fetuses of both sexes (male 6 and female 4) age ranging from 34 wks to 41 wks. Specimen containing cerebellum was collected from dead bodies autopsied on different dates from April'2009 to September'2009 at the autopsy laboratory of department of Forensic Medicine and Gynaecology and Obstetrics Department of Mymensingh Medical College, Mymensingh. The collected sample was grouped in to three age groups like Group A (34 to 41 weeks of gestation), Group B (5 to 30 years) and Group C (31 to 60 years) and two sex groups (male and female). 10 cerebellums were studied from each age group for this histological study. Sections were processed following standard histological procedure and were stained with Hematoxylin and Eosin stain. Slides were examined under 15X40 magnification for counting the number of Purkinje cell. In this study, the mean difference of number of Purkinje cell between age Groups A\&C was statistically highly significant $(p<0.001)$ but difference between Groups $A \& B$ and $B \& C$ statistically was not significant.
\end{abstract}

CBMJ-2013; Jan: Vol-02, No-01: P: 39-42

Key words: Cerebellum, Purkinje cell, Number, Bangladeshi cadaver.

\section{Introduction}

Cerebellum is the largest part of hindbrain, situated in the posterior cranial fossa, behind the pons and the medulla oblongata. .,2,3,4 $^{\text {The }}$ cerebellum is the portion of brain lying behind and below the cerebrum, it serves to coordinate both voluntary movements and muscle functions in the maintenance of normal posture. ${ }^{5}$

The cerebellum is a central part of the major circuit that links sensory to motor areas of the brain, and is required for the coordination of fine movement. In health, it provides corrections during movement, which are the basis for the precision and accuracy, and it is critically involved in motor learning and reflex modification. It receives sensory information through spinal, trigeminal and vestibulocerebellar pathways and, via the pontine nuclei, from the cerebral cortex and the tectum.

The human cerebellum is an enormously impressive organ. ${ }^{6}$ It unconsciously controls the smooth contraction of voluntary muscle and carefully coordinates their action. ${ }^{4}$

Cerebellum enlarges enormously during first year of life then the rate of growth is slow. The increase in volume is partly due to increase in the size and, not in number, of the nerve cells and partly by the growth of the blood vessels, but it is mainly affected by the
1. ${ }^{\star}$ Dr. A.Q.M. Ataul Haque

Associate Professor, Department of Anatomy, Kumudini Women's Medical College, Mirzapur, Tangail.

2. Professor Dr. Mohsin Khalil

Professor \& Head of the Department of Anatomy, Mymensingh Medical College, Mymensingh.

3. Dr. Seheli Zannat Sultana

Associate Professor, Department of Anatomy, Mymensingh Medical College.

4. Dr. Sabina Mannan

Assistant Professor, Department of Anatomy, Mymensingh Medical College, Mymensingh.

5. Professor Dr. Mahbubur Rahman Professor (C.C), Department of Anatomy, Community Based Medical College Bangladesh.

6. Dr. Muazzem Hossain

Associate Professor, Department of Anatomy, Kumudini Women's Medical College, Mirzapur, Tangail.

7. Dr. Anjuman Ara

Assistant Professor, Anatomy, Community Based Medical College Bangladesh.

8. Dr. Taslima Begum

Department of Anatomy, Community Based Medical College Bangladesh.

9. Dr. Shilpi Choudhury

Department of Anatomy, Mymensingh Medical College, Mymensingh, Bangladesh.

10. Dr. Nazia Haque

Medical Officer, Department of Microbiology, Mymensingh Medical College, Mymensingh, Bangladesh.

\section{*Address of correspondence \\ Email : atauldr@yahoo.com \\ Mobile : +801711273335}


progressive myelination of the nerve fibres. ${ }^{4}$ Cerebellar cortex consists of three layers outer molecular, intermediate Purkinje and inner granular. ${ }^{4}$ It contains more nerve cells (neurons) than all the rest of the brain combined, on an average 50 billion neurons. ${ }^{2,4,6}$ Purkinje cells form the center of a functional unit of the cerebellar cortex. They are flask-shaped and are arranged in a single layer. ${ }^{7}$ The total number of neurons in human cerebellum decreases significantly from early maturity to old age. ${ }^{8} \quad$ Studies of the structural-functional organization of different parts of the cerebellum continue to be relevant. The variety of cerebellar functions and the conditions associated with their impairments have led to multilateral studies of this organ. The neuronal organization of the cerebellum has been studied in detail by a number of authors. However, despite the significant number of reports addressing the structural organization of the cerebellum, most of these have been performed on animals but the number of Purkinje cell per high power field in humans remains inadequately studied. It has been observed by various workers that, dimensions of different organs in Bangladeshi population vary from those of western population. With the above evidences, the aim of the present work on number of Purkinje cell of cerebellum was to make a standard for Bangladeshi population.

\section{Methods:}

The study was done by examining 30 (thirty) cerebellum and samples were collected by using nonprobability sampling technique. Out of them 20 postmortem human cerebellum were collected from Bangladeshi cadavers of both sexes (male 10 and female 10). They were between 5 to 60 years of age.10 cerebellums were collected from dead fetuses of both sexes (male 6 and female 4) having an age range from 34 to 41 wks. Specimen containing cerebellum was collected from dead bodies autopsied on different dates from April'2009 to September'2009 at the autopsy laboratory of department of Forensic Medicine and Gynaecology and Obstetrics Department of Mymensingh Medical College, Mymensingh. All the collected specimens of postnatal cases were from medico-legal cases (suicidal, homicidal, or accidental death) and the specimen of foetus from intrauterine death cases (eclampsia, ante-partum haemorrhage, obstructed labour). Grossly injured cases involving head-neck region and cerebellum of decomposed bodies were excluded. The collected sample was grouped in to three age groups. They were Group $A$ (34 to 41 weeks of gestation), Group B (5 to 30 years) and Group C (31 to 60 years). Histological study was done on 10 cerebellum of each age group. Small pieces of tissue were taken and fixed in $10 \%$ formol saline. Size of the tissue was not more than $2 \mathrm{~cm} \mathrm{sq}$. and not more than $4-5 \mathrm{~mm}$ thick. Sections were processed following standard histological procedure and were stained with Hematoxylin and Eosin stain. One good slide prepared from each tissue block was chosen for study. 10 slides from 10 different cerebellums were taken from each age group. Thus 30 slides were examined under $15 \times 40$ magnification. From each slide 5 fields were chosen for counting the number of Purkinje cell. Thus in total 50 fields were examined from 10 slides of each age group. Observed mean number of Purkinje cell per HPF (15X40) were put down in a tabulated form for convenient processing which led to a conclusion. Appropriate statistical analysis was done using computer based statistical package, SPSS (Statistical Package for Social Science) to evaluate the significance of variance between the different findings.

\section{Result:}

In this study, significant differences was observed in the number of Purkinje cell per high power field in different age groups but no significant differences was observed between sexes. The details of observations are shown in Figure 2 and Tables I and II.

Mean number of Purkinje cell per high power field (15X40)

The mean $( \pm S D)$ number of Purkinje cell in Group A (34 to 41 weeks of gestation) was $3.56 \pm 0.14$, in Group B (5 to 30 years) was $2.98 \pm 0.12$ and Group $C$ (31 to 60 years) was $2.72 \pm 0.5$. It was maximum in Group A (3.56) and was minimum in Group C (2.72). So it was clearly observed that the mean number of Purkinje cell decreased with age (Table-I and figure-2). 
Original Article

The mean difference of number of Purkinje cell between Groups A\&C was statistically highly significant but differences between Groups A\&B and Groups B\&C was not statistically significant.

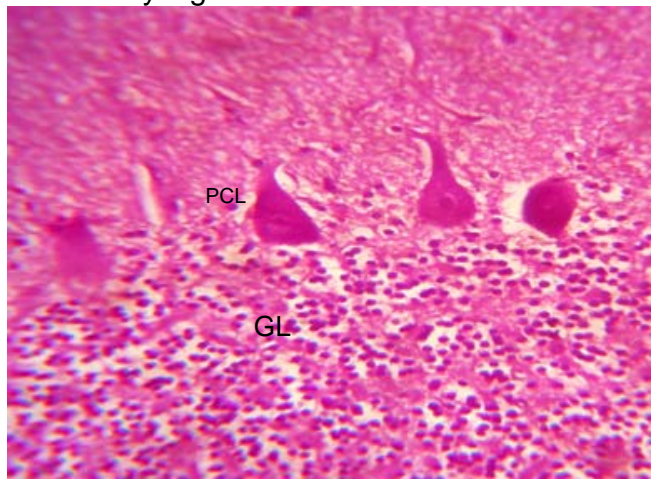

Figure 1: Photomicrograph of age Group B showing cerebellar cortex. H\&E stain: X40 $(\mathrm{GL}=$ Granular Layer, $\mathrm{ML}=$ Molecular Layer, $\mathrm{PCL}=$ Purkinje Cell Layer

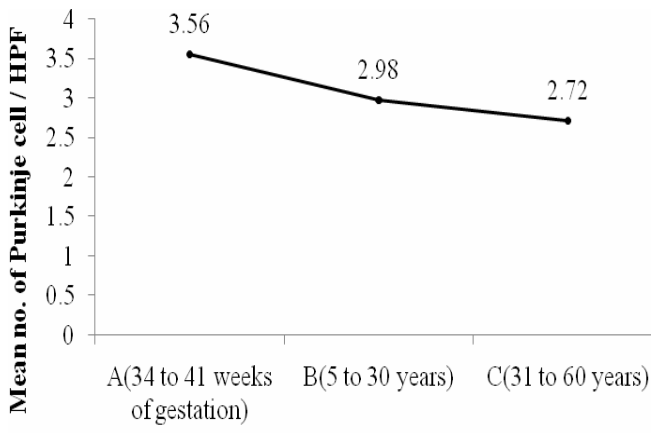

Age group

Figure 2: Line diagram showing the mean number of Purkinje cell in different age groups

Table I: Mean Number of Purkinje Cell among Different Age Groups

\begin{tabular}{|c|c|c|}
\hline \multirow[t]{2}{*}{ Age Group } & \multirow{2}{*}{$\begin{array}{l}\text { Number of } \\
\text { specimen }\end{array}$} & Mean number \\
\hline & & $\begin{array}{l}\text { Mean } \pm \text { SD } \\
\text { (Minimum- Maximum) }\end{array}$ \\
\hline $\begin{array}{c}\mathrm{A} \\
\text { (28-42 weeks of } \\
\text { gestation) }\end{array}$ & 10 & $\begin{array}{l}3.56 \pm 0.14 \\
(3.0-4.2)\end{array}$ \\
\hline $\begin{array}{c}\text { B } \\
\text { (Upto } 30 \text { years) }\end{array}$ & 10 & \begin{tabular}{|l|}
$2.98 \pm 0.12$ \\
$(2.4-3.8)$
\end{tabular} \\
\hline $\begin{array}{c}C \\
\text { (31 to } 60 \text { years) }\end{array}$ & 10 & $\begin{array}{l}2.72 \pm 0.15 \\
(2.0-3.4)\end{array}$ \\
\hline
\end{tabular}

Comparison of number of Purkinje cell among the age Groups

\begin{tabular}{|l|l|l|l|l|l|}
\hline $\begin{array}{l}\text { Relation } \\
\text { between } \\
\text { Variables }\end{array}$ & $\begin{array}{c}\text { Mean } \\
\text { Difference }\end{array}$ & $\begin{array}{c}\text { Std. } \\
\text { Error }\end{array}$ & $\mathrm{P}$ & Level of significance \\
\hline $\mathrm{A}$ & $\mathrm{B}$ & 0.58 & 0.19 & .005 & Not significant \\
\hline $\mathrm{A}$ & $\mathrm{C}$ & 0.84 & 0.19 & .000 & Highly significant \\
\hline $\mathrm{B}$ & $\mathrm{C}$ & 0.26 & 0.19 & .184 & Not significant \\
\hline
\end{tabular}

Table II: Mean Number of Purkinje Cell between Sexes

\begin{tabular}{|c|c|c|c|c|}
\hline Age Group & $\begin{array}{c}\text { Sex of } \\
\text { the } \\
\text { person }\end{array}$ & $\begin{array}{c}\text { Number } \\
\text { of } \\
\text { specimen }\end{array}$ & $\begin{array}{c}\text { Mean } \\
\text { number }\end{array}$ & $( \pm)$ SE \\
\hline $\begin{array}{c}\text { A } \\
\text { (34 to } 41 \text { weeks of } \\
\text { gestation) }\end{array}$ & Male & 6 & 3.68 & 0.19 \\
\cline { 2 - 5 } & Female & 4 & 3.44 & 0.20 \\
\hline B & Male & 5 & 2.84 & 0.18 \\
\cline { 2 - 5 } to 30 years) & Female & 5 & 3.12 & 0.20 \\
\hline $\begin{array}{c}\text { C } \\
\text { (31 to } 60 \text { years) })\end{array}$ & Male & 5 & 2.64 & 0.24 \\
\cline { 2 - 5 } & Female & 5 & 2.85 & 0.13 \\
\hline
\end{tabular}

Comparison of mean number of Purkinje cell between sexes

\begin{tabular}{|c|c|c|c|c|c|}
\hline $\begin{array}{c}\text { Age } \\
\text { Group }\end{array}$ & $\begin{array}{c}\text { Mean } \\
\text { difference } \\
\text { between } \\
\text { sexes }\end{array}$ & $\begin{array}{c}\text { Std. } \\
\text { Error } \\
\text { difference }\end{array}$ & $\mathrm{t}$ & $\mathrm{p}$ & $\begin{array}{c}\text { Level of } \\
\text { significance }\end{array}$ \\
\hline A & 0.24 & 0.27 & 0.90 & .397 & Not significant \\
\hline B & 0.28 & 0.24 & 1.19 & .271 & Not significant \\
\hline C & 0.22 & 0.32 & 0.69 & .511 & Not significant \\
\hline
\end{tabular}

Table-I depicts that the mean number of Purkinje cell was higher in male of Group A $(3.68 \pm 0.19)$ than that of female of Group A $(3.44 \pm 0.20)$ and this differences statistically was not significant, where for Group $A, t=$ 0.90 and $p=.397$ but the mean number of Purkinje cell was higher in female of Group B $(3.12 \pm 0.20)$ and Group $C(2.85 \pm 0.13)$ than that of male in Group B $(2.84 \pm 0.18)$ and Group C (2.64 \pm 0.24$)$ and statistically was not significant, where for Group B, $t=1.19$ and $p$ $=.271$ and for Group $C, t=0.69$ and $p=.511$.

The mean difference of number of Purkinje cell between sexes was statistically insignificant. 


\section{Discussion:}

The Purkinje cells are large Golgi type-I neurons. They are flask shaped and are arranged in a single layer. ${ }^{1}$

The present study was designed to study the number of Purkinje cell per high power field.

The sample of the study was arranged into Group A (34 to 41 weeks of gestation), Group B (5 to 30 years) and Group C (31 to 60 years) respectively. Fresh 30 (thirty) cerebellums were selected, 10 (male 5 \& female 5) from each age Group for this study. Sections were processed following standard histological procedure and were stained with Hematoxylin and Eosin stain and studied under 15X40 magnifications.

Mean number of Purkinje cell per high power field (15X40)

In present study, it was found that the mean $( \pm S D)$ number of Purkinje cell was in Group A $3.56 \pm 0.14$, in Group B 2.98 \pm 0.12 and in Group C $2.72 \pm 0.5$ and the mean number of Purkinje cell was maximum in Group A (3.56) and was minimum in Group C (2.72). A baby's brain has its full compliment of neurons by the sixth month of gestation. ${ }^{9}$ Differentiation process of cerebellar cells (Purkinje, granule, Golgi, basket and stellate cells) starts at $6^{\text {th }}$ month of foetal life and the process continues about 1 to 2 years of postnatal life ${ }^{10}$ Brain begins to shrink around the age of 30 due to neuronal loss. ${ }^{9}$ Dekaban and Sadowsky (1978) showed in their studies that there was a decrease in brain weight within the age interval of 30 to 90 years of age. ${ }^{11}$ In the present study the mean difference of number of Purkinje cell between Groups A\&C was statistically highly significant but difference between Groups A\&B and B\&C was not statistically significant. From this study it was concluded that the mean number of Purkinje cell decreased from birth to old age and the rate of decrease under 30 years of age was slow and was not statistically significant but it was statistically highly significant after 30 years of age. So Purkinje cell degenerates more rapidly in late age.

Dekaban and Sadowsky (1978) showed in their studies that mean brain size (weight or volume) is $9-12 \%$ larger in men than women. ${ }^{11}$ Men lose brain tissues more significantly than women (approximately 3 times faster). ${ }^{9}$ In the present study, it was observed that the mean number of Purkinje cell per high power field was higher in male than female in prenatal age group but higher in female than male in postnatal age group. So, the condition was reversed between sexes in late age groups may be due to the rate of degeneration of neuron is more in male than female but the difference was statistically insignificant (Table-I).

\section{Conclusion:}

The result of the present study will enrich the information pool regarding histology of the cerebellum of Bangladeshi people. To establish a standard further study is required by using large number of samples from different parts of Bangladesh.

\section{References:}

1. FitzGerald Turlough M J, Neuroanatomy. In: Gray's anatomy: the anatomical basis of clinical practice, $39^{\text {th }}$ ed, London: Churchill Livingston, 2005; p. 353-368.

2. Chaurasia $B D$, Human Anatomy Regional and Applied, Vol. 3, $4^{\text {th }}$ ed, Bangalore: CBS Publishers and Distributor, 2007; p. 233-6.

3. Sinnatamby C. S. Last's Anatomy: regional and applied, $11^{\text {th }}$ ed, London: Harcourt Publishers Limited, 2006; p. 479-81.

4. Datta A K, Essentials of Neuroanatomy, Part-4. $4^{\text {th }}$ ed, Kolkata: Current Books International, 2005; p. 159-73.

5. Ross M H, Kaya I G, Pawlina W. Histology: A Text And Atlas, $5^{\text {th }}$ ed. Philadelphia: Lippincott Williams \& Wilkins, 2006; pp. 322-3,360

6. Leiner $H C$ and Leiner $A L$, 'The Treasure at the Bottom of the Brain', New Horizons for Learning, 1997; http://www.newhorizons.org

7. Snell R S. Clinical Neuroanatomy, $8^{\text {th }}$ ed. Baltimore: Lippincott Williams and Wilkins, 2008; p. 219-40.

8. Khutoryan B. M. 'Quantitative Characterization of the Cellular Elements of Human Cerebellar Nuclei at Different Ages', Springer Science + Business Media, Inc. 2003; 124(4), p. 35 -7.

9. Brain Health \& Puzzles http://www.brainhealthandpuzzles.com/fun_fact s_about the_brain.htm/ 9

10. Datta A K, Essentials of Human Embryology, $4^{\text {th }}$ ed, Kolkata: Current Books International, 2006; p. 159-73.

11. Dekaban A S, Sadowsky D. 'Changes in brain weights during the span of human life: relation of brain weights to body heights and body weights', Ann Neurol, 1978; 4, p. 345-56. 